\title{
A “CURA GAY” EM REVISTA: O ESTEREÓTIPO SOBRE HOMOSSEXUAL NOS DISCURSOS DE VEJA E JUNIOR ${ }^{1}$
}

\author{
Amanda de Andrade Campo ${ }^{2}$ \\ Fabiano Ormaneze ${ }^{3}$
}

RESUMO: Este trabalho investiga a constituição, a formulação e a circulação de discursos sobre homossexualidade nas revistas Veja e Junior, mais precisamente publicações acerca do projeto de lei 234/11, que ficou conhecido como "Cura Gay". A partir do corpo teórico-metodológico da Escola Francesa de Análise de Discurso, a pesquisa procura compreender o processo discursivo que dá origem à imagem de homossexual posta em circulação em reportagens que abordavam a proposição de lei que, se aprovada, possibilitaria que psicólogos se envolvessem em tratamentos de "reversão" da homossexualidade. Para compor o corpus, foram selecionadas três edições de Veja e três de Junior, publicadas no primeiro semestre de 2013, o que permitiu a comparação entre uma mídia hegemônica e uma militante/segmentada. A partir da compreensão da memória das revistas e dos dizeres sobre homossexualidade na história, a análise foca-se nos efeitos de sentido que Veja constrói a partir da ironia e dos estereótipos que ligam a homossexualidade à promiscuidade. Em Junior, mesmo sendo voltada ao público homossexual, a revista se coloca como um discurso competente, de referência nas discussões sobre gênero e direitos aos gays, embora, muitas vezes, reforce e recupere a memória discursiva que materializa o estereótipo da promiscuidade, exemplificando, assim, como a produção dos discursos extrapola as meras

\footnotetext{
1 Este artigo é parte da monografia "A Cura Gay em revista: formulação e circulação de discursos em Veja e Junior", apresentada como Trabalho de Conclusão de Curso na Faculdade de Jornalismo da PUC-Campinas em 2013.

${ }^{2}$ Mestranda em Comunicação pelo Programa de Pós-Graduação em Comunicação da Pontifícia Universidade Católica do Rio Grande do Sul/Capes. Jornalista pela PUC-Campinas.

3 Professor-convidado na Escola de Extensão da Unicamp e no Centro Universitário Metrocamp (Unimetrocamp-Campinas/SP). Doutorando em Linguística na Unicamp, onde também fez mestrado. Jornalista pela PUCCampinas.
} 
causalidade e intencionalidade, envolvendo elementos que fogem à determinação.

Palavras-chave: Homossexualidade; revistas; discurso.

ABSTRACT: This work investigates the constitution, formulation and circulation of discourses on homosexuality in the magazines Veja and Junior, more precisely in the publications about the bill 234/11, which became known as "Gay Cure". From the theoretical and methodological body of the French School of Discourse Analysis, it seeks to understand the discursive process that gives rise to the image of homosexual put into circulation in articles that approached the proposition of law that, if approved, would allow psychologists to be involved in treatments of "reversal" of homosexuality. To compose the corpus, three editions of Veja and three of Junior, published in the first semester of 2013, were selected, which allowed the comparison between a hegemonic and militant / segmented media. From the understanding of the magazine memory and of the sayings on homosexuality, analysis shows that Veja constructs his discourse from the irony and stereotypes that link homosexuality to promiscuity. In Junior, even though it is aimed at the homosexual public, the magazine stands as a competent discourse, a reference in the discussions on gender and gay rights, although it often reinforces and recovers the discursive memory that materializes the stereotype of promiscuity, thus, as the production of discourses extrapolates mere causality and intentionality, involving elements that escape the determination.

Keywords: homosexuality; magazines; discourses.

\section{INTRODUÇÃO}

"Cura Gay" é o apelido do Projeto de Decreto Legislativo (PDL) n 234, proposto e documentado em 2011, pelo deputado João Campos (PSDB-GO). Em 18 de junho de 2013, o projeto foi aprovado na Comissão de Direitos Humanos e Minorias (CDHM), sob a presidência do pastor evangélico Marco Feliciano (PSC-SP). Em julho do mesmo ano, foi arquivado pela Câmara dos Deputados. No dia 15 de setembro de 2017, o juiz Waldemar Cláudio de Carvalho, da 14a Vara do Distrito Federal, concedeu liminar que autoriza e respalda legalmente profissionais da Psicologia a praticarem tratamentos de reversão da homossexualidade. Embora não seja o mesmo documento do deputado João Campos, os 
A “Cura Gay" em revista:

O estereótipo sobre homossexual nos discursos de Veja e Junior | 13

efeitos de circulação e de sentido são semelhantes. A repercussão midiática trouxe, novamente, a "cura gay" como forma de menção à liminar.

O projeto do deputado goiano previa a retirada de dois artigos que, em 1999, tinham sido abarcados na legislação do Conselho Federal de Psicologia (CFP). O primeiro artigo determinava que os psicólogos não colaborariam com eventos e/ou "tratamentos" de reversão da homossexualidade. O segundo determinava que os profissionais da Psicologia não se pronunciariam em público ou em qualquer veículo se o discurso indicasse a homossexualidade como uma desordem psíquica. É no bojo dessa compreensão que está situado este trabalho que, a partir do corpo teórico-metodológico da Escola Francesa de Análise de Discurso, objetiva compreender a constituição, a formulação e a circulação de discursos em duas revistas com propostas editorias distintas. Para contemplar esse objetivo, de compreender a constituição de discursos em meio a opacidade, a pesquisa está ancorada nos conceitos propostos por Michel Pêcheux (1975) e debatidos por Eni Orlandi ao longo dos últimos 30 anos.

\section{METODOLOGIA}

Para compor o corpus deste trabalho, foram selecionadas reportagens, gênero que, do ponto de vista da Comunicação Social/Jornalismo, segundo Marques de Melo (2006), permite uma visão ampla de um fato que já eclodiu. Para isso, foram analisadas duas publicações: Veja (revista semanal de maior circulação nacional, segundo a Associação Nacional de Revistas - ANR, publicada pela Editora Abril desde 1968) e Junior (revista segmentada, voltada ao público gay masculino, que circulou mensalmente entre 2007 e 2015), que abordaram a temática em questão. Foram selecionadas três edições de cada revista, publicadas entre março de 2013, quando Marco Feliciano foi eleito para a presidência da CDHM, e julho do mesmo ano, quando o projeto de lei esteve em evidência. As edições foram escolhidas de modo que se encaixassem nos critérios de seleção: uma entrevista pingue-pongue e duas reportagens em cada revista com chamadas de capa. A escolha desses materiais, por esses critérios, deve-se ao fato de tentar contemplar textos cujo foco seria, do ponto de vista do jornalismo, os definidos por Marques de Melo (2006). Esse recorte visou ainda contemplar o máximo possível de material das duas publicações sobre o assunto no período em questão. 
Ao compreender que a Análise de Discurso de Escola Francesa procura entender "como" o texto significa (ORLANDI, 2012) e não "o quê" esse texto quer dizer, optamos por analisar o objeto sob o prisma de tal teoria, uma vez que a escola de M. Pêcheux considera a linguagem como opaca, turva, ou seja, não transparente. Dessa forma, compreendemos a linguagem como agente de mediação (que é o discurso) entre o homem e a realidade natural e social, como bem recupera Orlandi (2012). Uma vez que os sujeitos que elaboraram as reportagens não são senhores de suas vontades (FOUCAULT, 1999), ou seja, não possuem controle total sobre os efeitos de sentidos de seus enunciados, quais são as ideologias que os interpelam? Quais são os discursos outros que estão presentes nos seus enunciados?

A Análise de Discurso Francesa leva em consideração a constituição histórica, com uma memória do que já foi dito, retomada nas novas enunciações, sem domínio do sujeito. O conceito de discurso, assim, é o de palavra em movimento (ORLANDI, 2012). Esse movimento produz o simbólico e, assim, faz parte também da constituição da humanidade e de sua história. Por isso, a Análise de Discurso está intimamente ligada às condições de produção e aos fatos históricos que cercam os temas propostos. Essa definição se completa com o fato de que o discurso, para Pêcheux, é o efeito de sentido entre locutores (ORLANDI, 2016), ou seja, as palavras (e os silêncios) têm seus sentidos construídos a partir da relação dos envolvidos na enunciação.

\section{"IMPRENSA COLORIDA": BREVE CONTEXTUALIZAÇÃO DAS PUBLICAÇÕES (AOS) GAYS}

Apesar de a Psicanálise de Freud dizer o contrário, o discurso médico dominante nos anos 1950 e 1960 colocava a homossexualidade como uma doença ${ }^{4}$, indicando tratamentos e punições. Nesse mesmo período, como resistência, mesmo no Brasil, já surgiam veículos de comunicação voltados ao público gay. Essas primeiras publicações tiveram um caráter de colunismo social se comparados aos produtos atuais. Como explica Lima (2011), foram veículos que não priorizavam as discussões sobre homossexualidade nem a disseminação de informação acerca da sexualidade:

${ }^{4}$ Um exemplo é o livro Homossexualismo Masculino, de Jorge Jaime, da década de 1950, que nomeava gays de "doentes sexuais" e de "doentes infelizes" (GREGORI, 1998). Freud, no entanto, em 1903, já afirmava que a homossexualidade não deveria ser tratada como doença (VIEIRA, 2009). 
Antes, em 1961, surge o que talvez possa ser chamado o primeiro jornal homossexual no Brasil: o Snob, criação de Agildo Guimarães. Mimeografado e distribuído entre amigos, era mais um colunismo social do que do que um veículo de discussão de ideias. Entre os anos 60 e o início dos anos 70, circularam no Rio de Janeiro mais 15 títulos: Snob, de Gilka Dantas, Le Femme, Subürbio à noite, Gente Gay, Aliança de Ativistas Homossexuais, Eros, La Saison, O Centauro, O VIc, O Grupo, Darling, Gay Press Magazine, 20 de Abril, O Centro e $\mathrm{O}$ Galo. Em Niterói surgem Os Felinos, Opinião, O mito e Le Sofistique. (LIMA, 2011, p. 02)

Foi na Bahia que houve a primeira aparição de um jornalismo voltado para os debates sobre a homossexualidade. Nos anos 1960 e 1970, originaram-se lá pelo menos sete periódicos ao público gay, de acordo com Lima (2011). Isso culminaria também com a criação do primeiro grupo de apoio a homossexuais formalizado no Brasil, o Grupo Gay da Bahia, fundado em 1980.

Porém, foi o jornal O Lampião o principal veículo desse período para tal público. Criado por João Silvério Trevisan (jornalista) e Peter Fry (antropólogo), iniciou a circulação numa época em que a ditadura perdia forças de repressão e trazia em sua primeira edição também um forte apoio aos movimentos feministas da época. No trabalho de Gregori (1998), é citada uma das manchetes da edição número 1: "A igreja e os Homo". Logo no início de suas publicações, o discurso de capa do periódico registra o grande desafio para a comunidade homossexual. As heranças de repressão do moralismo religioso eram tensionadas desde o princípio da imprensa homossexual no Brasil.

Depois de três anos de circulação, O Lampião teve sua última edição publicada em 1981. Os grandes motivos de sua falência foram, segundo Gregori (1998), a falta de anunciantes que sustentassem as despesas do jornal e o boicote das distribuidoras. Ainda, para Kucinski (1991), o fim do jornal foi se render ao apelo pornográfico. Para Lima (2011), foi nesse período que a imprensa homossexual se distanciava do 
viés crítico-informativo e se aproximava das características pornográficas. Nesse mesmo ano, circulavam as primeiras publicações mensais de $\mathrm{O}$ Jornal Gay que, de acordo com Gregori (1998), trazia os nus masculinos sem a genitália à mostra. $\mathrm{O}$ periódico de Antônio Kirihara seguia a linha do homoerotismo. Ainda nesse ano, as primeiras publicações destinadas às lésbicas apareceram com o tabloide Chanacomchana.

Na década de 1980, com o avanço da Aids no Brasil e no mundo, as publicações voltadas ao público gay praticamente dedicavam-se integralmente ao combate à doença e à prevenção. Nesse período, portanto, surgiram diversas publicações de caráter instrutivo:

Surgem assim, os boletins dos grupos ligados diretamente à Aids, como o Boletim ABIA, Associação Brasileira Interdisciplinar da Aids, o Boletim Pela Vidda, do Grupo Pela Vidda, entre outros, chegando ao Voz Posithiva, editado pela Organização NãoGovernamental "Gestos", voltado exclusivamente para os infectados pelo vírus. Outra publicação, Saber Viver, surgida em 1989, também se destina às pessoas que vivem com o vírus HIV. Fora esses, surgem também jornais e revistas de cunho mais cultural e de lazer como EntË, de 1994, distribuída apenas por assinaturas, O Grito de Alerta, e o Nós por exemplo (1992). (LIMA, 2011, p. 06)

Em 1992, surgia a revista Nós por exemplo criada pelo Núcleo de Orientação em Saúde Social (Noss). Voltada ao público gay masculino e feminino, a revista mesclava conteúdo de nudez e discussões relevantes para os homossexuais. Em sua quarta edição, o veículo trouxe na capa o nu masculino estampado pelas nádegas de um homem que estão parcialmente cobertas com sua roupa íntima e, logo abaixo, três chamadas de reportagens retratando a inserção de assuntos ligados às polêmicas homossexuais da época: "Triângulo Rosa", "Assumir-se? Por quê?", e "Aids". Nós por exemplo encerrou os trabalhos com pouco mais de um ano de existência e foi responsável pelos primeiros textos traduzidos de outros 
A "Cura Gay" em revista:

O estereótipo sobre homossexual nos discursos de Veja e Junior | 17

veículos internacionais que também traziam publicações ligadas às lutas sociais gays.

Com o propósito de reestabelecer no cenário da imprensa homossexual brasileira o caráter informativo e deixar o pornográfico para as produções estritamente eróticas, Nelson Feitosa dá origem à revista Sui Generis em janeiro de 1995, com circulação de 30 mil exemplares. O periódico se espelhou no formato de duas revistas estadunidenses, Sui Generis e Attitude e Out. A revista, que perdurou até 2000, não trazia cenas pornográficas, tampouco nu frontal. Na década de 1990, no entanto, o segmento de revistas gays contaria com o aparecimento da G Magazine, em 1997, cujo foco passou a ser o nu masculino frontal e com ereção. Segundo Monteiro (2000), a SG Press (editora da Sui Generis), publicou ainda outra revista similar à G Magazine, com o mesmo grau apelativo, chamada Homens (1997), que ficou pouco tempo em circulação.

Essas publicações ganharam mais espaço em 1997, com a Bananaloca, da editora Fractal Edições, que, junto com a G Magazine, publicava com ousadia ensaios eróticos masculinos de famosos nacionais e internacionais. A G Magazine foi a revista para o público gay com maior circulação na história do Brasil, só deixando de circular em junho de 2013.

O impasse entre publicações informativas e publicações eróticas persistiu mesmo depois que G Magazine passou por mudanças em sua linha editorial, se aproximando à Sui Generis. Porém, a sutileza ficou mais fácil de ser encontrada na linguagem do que nos ensaios fotográficos. Foi nesse contexto e com essas características que surgiram outros veículos que abordavam temas como saúde, família, bem-estar, lutas, direitos e, sem fugir do convencional, homens total ou parcialmente nus. "Paralelamente, surgiram três novas publicações voltadas para o público gay: as revistas Junior (2007), DOM - De Outro Modo (2007) e Aimé Primus inter pares (2008). A proposta dessas revistas era apresentar ao interlocutor homossexual uma nova linha editorial para as publicações de gênero" (SANTOS e VELOSO, 2009, p. 07). DOM e Aimé não passaram dos cinco anos em circulação.

O discurso produzido nessa nova etapa da imprensa sexual brasileira, segundo Santos e Veloso (2009), centra-se em produzir o sentido da naturalidade da homossexualidade, como forma de combater o discurso que caminha pela ideia da anormalidade sexual. Com sua primeira publicação em 2007, a revista Junior (pertencente à editora Mix Brasil) se diferenciava da G Magazine, principalmente, por não apresentar 
ensaios fotográficos de homens completamente nus, mas ensaios que se aproximam daqueles feitos em revistas de moda. Com as suas publicações voltadas para os interesses do homem gay moderno, as páginas visavam, de acordo com os editores, a dar espaço para assuntos como beleza, moda, lutas, direitos, cultura e lazer.

A revista Junior, segundo sua autodefinição, foi lançada com o objetivo de propor uma nova abordagem tanto da imprensa homossexual nacional, quanto dos próprios indivíduos homossexuais, público ao qual era destinada (SANTOS E VELOSO, 2009). A revista, portanto, passou a fazer parte de um novo momento do jornalismo gay nacional. Assim, pode-se dizer que a imprensa homossexual passou por três etapas antes de chegar ao cenário atual: a primeira com o periódico Snob e o caráter de colunismo social, seguido por O Lampião, que trouxe uma primeira reflexão sobre sexualidade e imprensa homossexual, e, por fim, a terceira fase, representada pela revista G Magazine e o homoerotismo publicado em suas páginas. Essa nova etapa em que Junior estava inserida, assim como os outros veículos, ligava-se ao momento histórico também da militância da comunidade. Sobre isso, Santos e Veloso (2009) afirmam que:

Através de um jornalismo mais culto, o público gay experimenta outra visibilidade perante a sociedade. Busca-se a extinção de estereótipos que afirmam o homossexual como o sujeito fútil e fanático por pornografia, que dá lugar à imagem do gay moderno que entende sobre artes, cultura e finanças. As publicações desse gênero na contemporaneidade trabalham esses conceitos através de uma linha editorial que estimula a vaidade do leitor. Através de matérias e reportagens abordando questões estéticas e assuntos de interesse geral, essas revistas e sites provocam o despertar de uma identidade fundamentada na preocupação com a própria imagem, aproveitando-se do surgimento dos fenômenos de comportamento modernos que implicam na apreensão de um novo mundo orientado por 
A "Cura Gay" em revista:

O estereótipo sobre homossexual nos discursos de Veja e Junior | 19

padrões estéticos. Nessa linha de pensamento cabe ressaltar o quando o mercado editorial reconheceu a importância social e econômica que os gays conquistaram através de vários anos de buscas e batalhas em busca de mais visibilidade na sociedade assim como representações e respeito para a sua comunidade. (p. 10)

Esse breve histórico é importante para este trabalho à medida que oferece elementos para a compreensão não só das condições de produção do discurso de Junior e Veja analisados a seguir, como também das evidências de como a memória sobre publicações para gays e assuntos voltados a esse público foram se constituindo historicamente.

\section{ANÁLISE E CONSIDERAÇÕES}

De modo a possibilitar uma comparação, considerando os mesmos gêneros discursivos, a pesquisa compôs o corpus com uma entrevista pingue-pongue (como é conhecida no jornalismo a estrutura de perguntas e respostas) de cada veículo e duas reportagens que mereceram chamadas de capa nas edições. Estar na capa dos periódicos é um indicativo de que os editores as consideram entre as mais importantes na edição e entre as que mais interessam aos interlocutores.

Apresentamos, portanto, uma síntese do material selecionado para a análise, de acordo com o recorte. Para efeitos de menção, as matérias foram numeradas como V1, V2 e V3, no caso das publicações de Veja, e J1, J2 e J3, no caso das publicações e Junior:

a) V1: em formato de entrevista (pingue-pongue), na edição 2313, de 20 de março de 2013. Contém três páginas. O entrevistado é o deputado Marco Feliciano (PSC), que aprovou na CDHM o projeto "Cura Gay".

b) V2: reportagem cujo conteúdo é baseado na revelação da homossexualidade da cantora Daniela Mercury ao longo de dez páginas e na repercussão do acontecimento principalmente entre os grupos gays. Compõem a edição 2316, de 10 de abril de 2013. A reportagem tem como título "A revelação pública de Daniela". É também a matéria principal na capa. 
c) V3: reportagem de capa da edição de 3 de julho de 2013 da Veja São Paulo, um suplemento de Veja distribuído em cidades com distância de até cem quilômetros da capital paulista. Com o título "Nos bastidores da Cura Gay", busca retratar a postura dos pastores das maiores igrejas evangélicas da cidade de São Paulo.

d) J1: reportagem da edição 51, do mês de maio de 2013. Foram três páginas dedicadas à reportagem. O título da matéria é "Rumo ao céu". Apresenta ao leitor possibilidades de igrejas inclusivas, denominações evangélicas que acolhem homossexuais. Relata o caso do Padre Beto, excomungado pela Igreja Católica após se apresentar favorável aos direitos civis gays.

e) J2: Na edição 52, de junho, entrevista (pingue-pongue) de quatro páginas com a cantora Daniela Mercury, que assumira a homossexualidade. O título é "Nossa Diva".

f) J3: tem duas páginas, aborda as manifestações pelos direitos civis da comunidade LGBT. A edição 53 é do mês de julho de 2013. O título é "O país das manifestações".

A análise dessas reportagens leva em considerações três momentos, descritos a seguir: os pré-construídos, os operadores argumentativos e os verbos introdutórios de opinião, que apresentam a menção ao discurso de pessoas ouvidas pelas revistas.

\section{Dos pré-construídos aos estereótipos}

Pereira (2005) diz que "as palavras dos discursos que passam a cercar o indivíduo vêm carregadas de significações, descrevendo e interpretando o mundo que ele tem para viver" (p. 76). Algumas dessas palavras e, por consequência, os sentidos produzidos, por serem reforçados, repetidos exaustivamente ao longo da história e por estarem associados aos grupos dominantes, constituem-se como estereótipos, ou seja, uma memória "que funciona como uma marca, em um enunciado individual, de discursos e juízos prévios, cuja origem foi apagada" (AMOSSY; PIERROT, 2005, p. 113). O estereótipo seria, assim, a cristalização de um pré-construído, ou seja, uma imagem que fala antes, de outro lugar, na história e pela história, irrompendo no discurso (PÊCHEUX, [1975] 1989).

O estereótipo do que seja um homossexual, que, como veremos, passa a constituir o imaginário nas revistas, está intimamente ligado ao 
A "Cura Gay" em revista:

O estereótipo sobre homossexual nos discursos de Veja e Junior | 21

histórico da sexualidade, bem como ao desenvolvimento da mídia homossexual. Na primeira reportagem de Junior aqui analisada, "Rumo ao Céu" (J1), a revista traz para o leitor algumas alternativas de igrejas evangélicas ao redor do Brasil, as chamadas Igrejas Inclusivas. Em um momento em que a bancada evangélica presidia a Comissão de Direitos Humanos e Minorias (CDHM) e, dentre outras propostas, apresentava o projeto "Cura Gay", Junior publicou uma reportagem que funciona como a invocação de uma alternativa aos homossexuais que querem participar de uma igreja evangélica, mas não se veem representados por Marco Feliciano.

A reportagem sobre a igreja inclusiva serve como uma forma de desqualificar o discurso compreendido como homofóbico por Júnior. As questões religiosas fazem parte da luta homossexual, como ficou evidenciado no breve histórico da mídia dirigida a esse público no Brasil. A importância que a religião adquiriu historicamente na sociedade e as constantes repressões ao desejo homossexual desde a Idade Média fizeram com que o assunto figurasse em reportagens de revistas militantes em diferentes momentos.

Na reportagem J1, um box azul contém informações sobre como as Igrejas Inclusivas determinam os valores do sexo para os homossexuais. Nela aparece o seguinte trecho:

Os casais devem receber as bênçãos tradicionais religiosas antes de fazerem sexo. Sexo sem compromisso não é apropriado. Nem sexo anônimo, grupal. A pornografia também é condenada. O fiel deve orar para encontrar um amor e se dedicar a ele. Saunas e Sex Clubs não são ambientes apropriados para os fiéis (JUNIOR, 2013a, p.55, grifos nossos).

Essa reportagem traz o discurso da promiscuidade intimamente e historicamente ligado à homossexualidade. Considerando que o box está no alto da página ímpar (campo nobre e predominante de visão em revistas), o elemento gráfico é um texto que foi destacado, o que mostra a presença forte desse estereótipo: o sexual e erótico. Quando o jornalista escreve "Nem sexo anônimo, grupal", carrega a ideia de que essa prática é corriqueira entre os gays, e que a relação homossexual é carregada dessas 
imagens cristalizadas. Essa ligação direta com o sexual também se constitui como memória da própria mídia para a comunidade homossexual, uma vez que, como abordado anteriormente, em boa parte dos veículos a presença do erótico e do pornográfico foram características editoriais.

Em Veja, nota-se a presença do discurso similarmente construído, porém mais distante da pornografia e mais próxima à imagem de uma "vida desregrada". Em V3, o jornalista relata a história de um personagem que, quando adolescente, começou a se vestir de mulher e logo se tornou transformista. No texto, o jornalista escreve: "Ele começou a se vestir de mulher aos 16 anos, mas conta que sentia atração por meninos desde os 12. Cocaína e Maconha entraram rápido na sua rotina." (VEJA, 2013c, p. 41).

A escolha da oração final do trecho transcrito é capaz de produzir a imagem do que seria o natural na rotina de um transformista. A expressão "entraram rápido em sua rotina" produz a interpretação de que drogas e homossexualidade também estão intimamente ligadas, reforçando o estereótipo da vida problemática, à margem.

A guerra secular travada entre religião e homossexualidade, por outro lado, é tratada pelo discurso de Junior como anestesiada, porém ainda existente. Em outro box da mesma reportagem, a revista publica um texto de meia página sobre Padre Beto, defensor da tolerância religiosa acerca dos direitos civis de homossexualidade. No trecho:

Impressionante a decisão da Igreja Católica de excomungar o Padre Beto, de Bauru, por ele ter defendido direitos civis de homossexuais. O padre postou vídeos na internet em que defendia uma maior abertura para discutir as novas questões da sexualidade. $\mathrm{O}$ bispo pediu para ele tirar os vídeos e se retratar publicamente. Ele não quis. Preferiu se demitir. O padre fez sua última missa e escreveu a carta de demissão. Poderia terminar aí essa história. Mas não: a Igreja deu um passo além da intolerância e tomou a atitude descabida de excomungá-lo (JUNIOR, 2013a, p. 56). 
A "Cura Gay" em revista:

O estereótipo sobre homossexual nos discursos de Veja e Junior | 23

$\mathrm{Na}$ primeira reportagem analisada de Junior, portanto, transparece não só o estereótipo do homossexual ligado à promiscuidade e ao erotismo, mas também os estereótipos heroicos daqueles que compram as lutas gays perante aquela que é indicada como seu grande opressor: a Igreja.

Além disso, há o trecho "Ainda que não reconhecidas pelos setores evangélicos tradicionais, as igrejas inclusivas estão ganhando cada vez mais projeção. $\mathrm{O}$ próximo passo, segundo pastores ouvidos nessa reportagem, é criar espaços nos veículos de comunicação” (JUNIOR, 2013a, p. 56), que reforça a ideia de espaço alternativo, à margem, assumido pelas Igrejas Inclusivas no contexto atual da homossexualidade no Brasil. Ou seja, a revista dá a esses templos o espaço de sofrimento, de exclusão, o mesmo lugar que ocuparia o homossexual na sociedade.

Na segunda reportagem de Junior ("Nossa Diva"), do mês de junho, o estereótipo do heroico/simbólico foi transferido para a Daniela Mercury. Enquanto, na edição anterior, o Padre Beto assumiu o papel quando apoiou os direitos civis dos homossexuais e destacou os dogmas religiosos da Igreja, Daniela Mercury trouxe novamente à capa de um veículo homossexual outro grande desafio da experiência gay: o assumir-se para a sociedade.

Portanto, nota-se a presença de diferentes estereótipos de heróis no discurso da militância: aqueles que se opuseram aos padrões morais da religião/Igreja, representados pelas Igrejas Inclusivas e pelo Padre Beto, que enfrentaram as posições de suas opções religiosas, e aqueles que assumiram a homossexualidade e deram tanto força quanto visibilidade a essa minoria homossexual, incorporado pela cantora Daniela Mercury. Ou seja, o fato de alguém importante assumir nesse momento sua relação homossexual cabe, aqui, como uma vitória para a comunidade.

Estereótipos negativos em relação aos homossexuais também estão presentes em Veja. A vida cotidiana dos gays ligados à sensualidade, ao erotismo e ao desregramento é um constituinte da imagem do homossexual. $O$ que foge às determinações sociais heterossexistas é considerado como distúrbio, mesmo que implicitamente nos discursos das revistas Veja e Junior.

A "Cura Gay", muitas vezes, não está nas reportagens exatamente colocada com essas palavras, mas a ideia de distúrbio de comportamento remete ao indivíduo que é passivo de cura, com alguma enfermidade sexual ou psicológica, como é visto no trecho de V3: "O trabalho de libertação, como dizem nas igrejas evangélicas, acabou criando um novo 
gênero: os ex-gays. Eles são quase como propagandas ambulantes do processo, apontados como provas vivas de que, com ajuda de Deus, é possível transformar sua orientação sexual” (VEJA, 2013c, p. 41).

Os militantes que se manifestaram durante o primeiro semestre de 2013 também ganharam características marcantes de um estereótipo negativo na revista Veja. Enquanto Junior coloca-se como parte da militância, encorajando e incentivando os movimentos gays, Veja desqualifica o discurso de Daniela Mercury, a "diva" dos homossexuais, da mesma forma que estereotipa negativamente os manifestantes.

A desqualificação do discurso de Daniela Mercury é produzida pela reportagem $\mathrm{V} 2$, quando a revista narra o novo relacionamento divulgado pela cantora para a sociedade. A revista da Editora Abril publica, como primeira frase, uma fala de Daniela que diz "Seja o que Deus quiser, Malu", explicando o momento em que as mulheres assumiram via rede social o relacionamento para o mundo. Em seguida, logo no próximo parágrafo, Veja coloca: "Mas, pelo menos até que Ele a convoque para um acerto de contas, Daniela tem pouco com que se preocupar com as repercussões religiosas de seu anúncio. $\mathrm{O}$ casamento gay tem hoje mais implicações de ordem prática de que de consciência”. (VEJA, 2013b, p. 70)

Usando o operador argumentativo da ironia ${ }^{5}$, Veja faz referência aos termos usados pela igreja para designar penitência. Na passagem, a ironia também pode ser colocada com um desqualificador do discurso, dessa vez, da própria religião, através de termos como "acerto de contas" com o divino, que faz alusão a um juízo final, deixando, assim, a interpretação de que o ato homossexual é, de fato, inaceitável aos olhos do Deus católico. A desqualificação vem pelo final da sentença: “(...) O casamento gay tem hoje mais implicações de ordem prática de que de consciência".

Ao longo da reportagem, Veja relata a opinião da cantora que diz: "Numa época em que temos um Feliciano desrespeitando os direitos humanos, grito meu amor aos sete ventos. Quem sabe haja alguma lucidez no congresso brasileiro". (VEJA, 2013b, p.70). No mesmo parágrafo, o veículo desqualifica-a: "Ao misturar seu relacionamento com política, Daniela prestou um desserviço ao mesmo tempo ao romantismo e à sua seriedade de propósitos” (VEJA, 2013b, p. 70).

\footnotetext{
${ }^{5}$ Ironia é a distância intencional daquilo que o enunciador realmente deseja dizer. Entende-se a ironia no discurso não só como um recurso estilístico literário, mas como um recurso gerador de sentidos satíricos do tema em questão.
} 
A "Cura Gay" em revista:

O estereótipo sobre homossexual nos discursos de Veja e Junior | 25

Para dar credibilidade à sua afirmação, Veja coloca o discurso do presidente do Supremo Tribunal Federal (STF), Joaquim Barbosa, como o discurso competente, autorizado a analisar, a dar sua opinião, pelo lugar ocupado socialmente por sua fala. $\mathrm{O}$ presidente diz que é democrático haver divergências na política, formando-se, assim, a democracia. O que enfatiza essa ideia de concordância da revista em relação ao discurso do presidente do STF é, principalmente, a forma como Veja faz referência a ele: "O presidente do STF, Joaquim Barbosa, ajudou a pôr a questão em sua real perspectiva" (VEJA, 2013b, p. 70). O verbo "ajudar" e a nomeação "real perspectiva" acrescentaram força de argumentação ao discurso da revista e do presidente.

O discurso da militância e dos manifestantes das causas homossexuais também foi desqualificado pela revista, bem como os propósitos e os meios de atingir os objetivos das lutas. Veja afirma serem importantes as mudanças sociais, mas, em contrapartida, o modo como construiu seu discurso produz o sentido de que a militância age de forma equivocada:

É natural e positivo que as instituições tratem as mudanças comportamentais radicais com cautela devida. É natural e positivo também que as pessoas passam ter tempo para se acostumar com esses novos ordenamentos sociais e avanços comportamentais. É assim que as mudanças se legitimam, superando a intolerância, que se dilui com o tempo em formas cada vez mais brandas de rejeição até se tornarem invisíveis (VEJA, 2013b, p.70, grifos nossos).

No trecho, também fica evidente a forte presença de adjetivos, utilizados por Veja como estratégia de argumentação, como a utilização das palavras "natural", "positivo", "brandas" e "invisíveis". Ainda: Veja utiliza o exemplo da Suprema Corte dos Estados Unidos que, em palavras da revista, "optou pela cautela". O veículo conta que o órgão pediu mais tempo para que qualquer decisão sobre casamento gay fosse tomada pelos juízes de um "provável" reconhecimento legal. A presença dessas palavras produz o sentido de aceitação do discurso correto dos Estados Unidos e a 
memória de que o Brasil deve acompanhar as decisões dos países desenvolvidos.

Ao final da reportagem, outro estereótipo negativo é retomado por Veja. A revista cria a imagem de militantes perturbadores, julgando as manifestações como agressivas e intolerantes: "Além da intolerância e agressividade dos militantes, há descontentamento de bom número de pessoas com a redução das questões éticas de alta complexidade - caso também do aborto e da eutanásia - a uma simples luta por direito" (VEJA, 2013b, p 74).

É importante ressaltar que Veja não utiliza citações ou dados estatísticos que, no discurso jornalístico, dariam credibilidade a essa informação. Isso produz o sentido de que a revista dá a si mesma a competência para tais afirmações, sem atribuir a outrem. Por fim, coloca de forma sutil seu posicionamento sobre o casamento gay, o que o veículo considera um terreno desconhecido: "O reconhecimento do direito dos homossexuais é, portanto, apenas um aspecto de uma questão social de consequências ainda não totalmente conhecidas” (VEJA, 2013b, p. 75). Esse trecho aparece como uma marca do conservadorismo, ou seja, da tentativa de manter as instituições (casamento, família etc.) conforme o discurso dominante e estabilizado, sem reconhecer a possibilidade de mudanças.

A forma como Junior formula seu discurso, ao publicar matérias sobre esses mesmos manifestantes que Veja considera violentos, é distinta. Na reportagem J3, Junior introduz: "Rodrigo Ribeiro é um dos milhares de jovens que saíram às ruas do Brasil no mês de junho para protestar contra uma lista de coisas que consideram erradas no país" (JUNIOR, 2013c, p. 36, grifo nosso). A revista militante utiliza "protestar", palavra que produz o sentido democrático das manifestações e, assim, enaltece o caráter de participação social da militância.

Veja, num discurso irônico e sarcástico, também estabeleceu estereótipo de homossexual na matéria V1, entrevista com o deputado Marco Feliciano (PSC). No início, a revista recorre à seguinte sentença: "O deputado federal Marco Feliciano é metrossexual. Calma. A palavra define homens muito preocupados com a aparência, e ele preenche os requisitos básicos: alisa os cabelos, desenha as sobrancelhas, gosta de perfume, usa anel” (VEJA, 2013a, p. 17, grifos nossos). Na citação, encontramos não só a caracterização de um homem vaidoso. Há também o discurso não dito do estereótipo do homem afeminado, necessariamente de conduta homossexual. Quando a revista usa "Calma”, 
A “Cura Gay" em revista:

O estereótipo sobre homossexual nos discursos de Veja e Junior | 27

que aparece como palavra única de uma sentença, ela antecipa-se a explicitar que, além da semelhança formal com a palavra "metrossexual", há também uma proximidade de conduta das pessoas que se encaixam nas duas classificações, transparecendo, assim, o estereótipo do afeminado. Isso fica ainda mais claro quando se retoma a origem da expressão "metrossexual". A palavra foi cunhada para se referir a homens vaidosos e heterossexuais para que se distanciasse deles qualquer ligação à homossexualidade, já que, em geral, a vaidade masculina sempre foi sinônimo de dúvidas em relação à masculinidade.

A partir desses pré-construídos, a revista, ao construir o texto dessa forma, com ironia e trocadilhos, retoma um dizer muito frequente nas redes sociais durante o período: militantes e críticos, em geral, fizeram muitas montagens de Feliciano em posições ou com frases de forte ligação com a homossexualidade ou com o estereótipo homossexual. Muitas vezes, Feliciano foi retratado como sendo gay.

\section{Operadores argumentativos}

Veja utiliza "expressões equivalentes e adjetivos" (SILVA, 1997, p. 83) como operadores argumentativos ou marcas argumentativas. Numa tentativa de ressaltar o trabalho feito pelo jornalista e pela revista enquanto instituição, e ironizar a postura do pastor Marco Feliciano, esses operadores também aparecem no começo da entrevista com Feliciano (V1): "Paulista de Orlândia, onde mora com a mulher, pastora e três filhas, ele fala com grande franqueza sobre os assuntos em questão e certos atos exóticos praticados em Brasília”. (VEJA, 2013a, p. 17) No trecho, Veja utiliza "grande franqueza" e "atos exóticos" como marcas argumentativas.

Outras marcas argumentativas encontradas na entrevista são: os recursos estilísticos da metáfora ${ }^{6}$, do trocadilho ${ }^{7}$ e da ironia, que, segundo Silva (1997), "dão conta de estabelecer entre o locutor e o alocutário uma interação própria do conhecimento de mundo que compartilham" (SILVA, 1997, p. 86). Silva explica ainda que o leitor consegue perceber o sentido do discurso irônico e metafórico, principalmente, por

\footnotetext{
${ }^{6}$ Metáfora é um recurso estilístico, uma figura de linguagem em que o que é dito adquire um sentido não muito comum, durante a relação de semelhança entre os termos utilizados. Ou seja, um termo substitui o outro.

${ }^{7} \mathrm{Um}$ recurso retórico comumente utilizado em discursos humorísticos, o trocadilho é o fruto da semelhança de som (fonética) ou de sentido entre duas palavras.
} 
contextualizar internamente o fato e as circunstâncias em que o discurso foi elaborado.

$\mathrm{Na}$ passagem "Pastor pela Assembleia de Deus, ele foi indicado pelo Partido Social Cristão para presidir a Comissão de Direitos da Câmara e abriu as portas do inferno" (VEJA, 2013a, p. 17), Veja utiliza a metáfora e o trocadilho para unir imagens apreendidas pelo leitor e enraizadas no discurso do senso-comum. Dois sentidos são possíveis pela polissemia da palavra "inferno", utilizada para montar o discurso: o primeiro é a relação entre as minorias (homossexuais, negras etc) e a Igreja, historicamente conturbada (uma marca da historicidade), o outro é a junção das informações sobre a opção religiosa do pastor e a conduta que mantém como parlamentar.

Veja finaliza a entrevista com uma pergunta que retoma o estereótipo do homossexual afeminado, ironizando os costumes de Marco Feliciano com a aparência. Depois de ter perguntado ao deputado: “O que o senhor acha da teoria segundo a qual impulsos homossexuais podem desencadear comportamentos agressivos em relação a gays?" (VEJA, 2013a, p. 20), Veja encerra a entrevista questionando as práticas de Feliciano, retomando a ideia inicial do primeiro parágrafo dessa matéria, e utilizando o recurso da ironia: "Além de fazer progressiva, o senhor tira as sobrancelhas?” (VEJA, 2013a, p. 21). Em sua resposta, Feliciano se apoia nos argumentos biológicos e diz que tem essas práticas devido ao "excesso de hormônios", remete ao estereótipo do "machão", do viril. Veja, então, termina a reportagem da mesma forma como começou: recuperando o discurso de Feliciano como uma pessoa com tendências à homossexualidade, relacionando-a com feminilidade e cuidados estéticos.

Assim como Veja, Junior faz uso de adjetivos e metáforas, utilizados como marca argumentativa. Essas estratégias servem para validar e exaltar o que está sendo dito pela revista. Em J2, a revista introduz a entrevista com Daniela Mercury com um parágrafo baseado nesses recursos:

O calor do repique baiano esquenta uma tarde fria de outono em São Paulo. De dentro de uma sala de ensaios do CLAM Centro Livre de Aprendizagem Musical, no bairro de Moema, uma voz conhecida canta "Por amor ao Ilê" acompanhada pela formação atual do histórico Zimbo Trio. É a voz marcante de Daniela Mercury, rainha do 
A "Cura Gay" em revista:

O estereótipo sobre homossexual nos discursos de Veja e Junior | 29

axé, rainha da energia boa e agora rainha da luta contra a homofobia (JUNIOR, 2013b, p. 22, grifos nossos).

Nota-se, no trecho destacado, uma espécie de resumo da construção de imagem que Junior faz da cantora, por meio de enunciados anteriores, como é o caso de: "uma beleza que fica ainda maior quando se está perto dela” (JUNIOR, 2013c, p.23). Nessa sentença, o veículo militante usa o articulador "ainda" para somar argumentos e qualidades já pré-construídos no início da matéria, além de exaltar a imagem da cantora.

Ao longo da entrevista, Junior constrói um caminho a ser percorrido por Daniela rumo aos sentidos que a revista pretende produzir como espaço de militância. A primeira pergunta para a cantora diz respeito à maior manifestação gay anual: a Parada do Orgulho Gay: "Como foi o convite para participar da Parada em São Paulo? Eu sei que vocês antes já tentavam essa participação, mas nunca tinha dado certo a agenda” (JUNIOR, 2013c, p. 24). Nessa pergunta, o jornalista já introduz o sentido de que a cantora é, há tempos, uma simpatizante das causas gays, mesmo antes de se assumir publicamente. Isso ainda permite interpretar que seria uma "honra" para a cantora participar do evento, o que funciona para criar uma identificação ainda maior do leitor para com Daniela, reforçando, assim, sua imagem de ícone para a comunidade. Novamente, o jornalista se coloca como discurso competente para afirmar essa vontade da cantora, sem citar fontes, como se o sentido fosse evidente: "eu sei".

A "Cura Gay" na entrevista aparece só na quinta pergunta, ligada também aos avanços positivos dos direitos civis dos homossexuais. Primeiro, a revista deixa evidente a cantora como ícone, como heroína, como simpatizante das causas gays, como parte das lutas homossexuais e como um reforço para elas. Depois, o veículo coloca em questão as causas pelas quais ela e toda a classe gay lutam, por meio da pergunta: "E o que você acha desse momento atual do Brasil, onde temos avanços tão importantes quanto o casamento ao mesmo tempo em que temos Marco Feliciano e projeto de cura gay?" (JUNIOR, 2013c, p. 25). É possível perceber os contrastes que a revista cria, mesmo sem dizê-lo. Com a pergunta e o modo como foi elaborada, Junior coloca no mínimo três momentos históricos das lutas homossexuais: o primeiro e mais claro é o casamento gay como direito civil, dando o primeiro tom positivo à 
pergunta; o segundo é o contraponto representado por Feliciano e, por fim, o terceiro sentido de que a "Cura Gay" é um impasse já superado, tanto pelas atuais posições da Medicina, quanto pelos direitos civis. Portanto, ao mesmo tempo em que Junior cria a imagem dos ícones favoráveis às lutas gays, ela também transfere o papel do vilão para um dos personagens do cenário atual das manifestações e conflitos sobre homossexualidade: Marco Feliciano.

\section{Verbos Introdutórios de opinião}

Em Veja, a reportagem destinada à explicação do que leva os religiosos evangélicos a pregarem contra a homossexualidade e a favor de uma conversão dos homossexuais em heterossexuais foi construída com base nas falas negativas dos líderes dessas igrejas, apoiadas em verbos que introduziram as opiniões e produziram diferentes sentidos para a fala da fonte de informação.

A classificação dos verbos introdutórios de sentido e de opinião usada neste trabalho é aquela desenvolvida por Marcuschi (2007). Segundo o autor, os verbos introdutórios de opinião são utilizados como argumentativos do próprio autor do texto jornalístico, exercendo a função de organizar o discurso:

Os verbos introdutores de opinião têm uma função organizadora daquele texto préexistente que pode ser oral ou escrito. Não se trata de uma atividade argumentativa, nem de uma ação direta do discurso relatado, e, sim de uma função construtora dos argumentos do autor (MARCUSCHI, 2007, p.163).

Marcuschi (2007) elenca sete categorias de verbos introdutórios. Essas classes gerais de funções organizadoras são:

1) Verbos indicadores de posições oficiais e afirmações positivas (declarar, afirmar, comunicar, anunciar, informar, confirmar, assegurar).

2) Verbos indicadores de força do argumento (frisar, ressaltar, sublinhar, acentuar, enfatizar, destacar, garantir).

3) Verbos indicadores de emocionalidade circunstancial (desabafar, gritar, vociferar, esbravejar, apelar, ironizar). 
A “Cura Gay" em revista:

O estereótipo sobre homossexual nos discursos de Veja e Junior | 31

4) Verbos indicadores de provisoriedade de argumento (achar, julgar, acreditar, imaginar).

5) Verbos organizadores de um momento argumentativo no conjunto do discurso (iniciar, prosseguir, introduzir, concluir, inferir, acrescentar, continuar, finalizar e explicar).

6) Verbos indicadores de retomadas opositivas, organizadores dos aspectos conflituosos (comentar, reiterar, reafirmar, negar, discordar, temer, admitir, apartear, revidar, retrucar, responder, indagar, defender, reconhecer, reconsiderar, reagir).

7) Verbos interpretativos do caráter ilocutivo do discurso referido (aconselhar, criticar, advertir, enaltecer, elogiar, prometer, condenar, censurar, desaprovar, incentivar, sugerir, exortar, admoestar).

Além dessas classes, o verbo "dizer" tem, de acordo com o autor, a finalidade de curinga, com sentido mais próximo ao ideal de objetividade buscado pelo jornalismo. Além disso, "dizer" pode assumir todas as funções já ditas, dependendo da fala a que se refere. A fim de criar um critério de análise mais rigoroso, foram selecionadas, para este artigo, apenas duas reportagens do corpus que abordam o tema "religião evangélica x homossexualidade" (V3 e J1). Foram construídas duas tabelas a partir da classificação de Marcuschi:

\section{Tabela 1 - Verbos introdutórios em V3}

\begin{tabular}{|c|c|c|}
\hline Classificação & Verbos introdutórios de opinião e sentido & Total \\
\hline 1 & Contar (2), Afirmar, Descrever, Observar & 05 \\
\hline 2 & Garantir & 01 \\
\hline 3 & Confessar & 01 \\
\hline 5 & Lembrar & 01 \\
\hline 6 & Considerar, Revelar & 02 \\
\hline 7 & Aconselhar, Amenizar, Sugerir (2), Penitenciar & 05 \\
\hline Curinga & Dizer (3) & 03 \\
\hline
\end{tabular}

Para Marcuschi (2007), a função dos verbos introdutórios de opinião é de, sobretudo, organizar o texto e seus argumentos dentro das estruturas linguísticas. Na reportagem V3, o curinga "dizer" é o mais utilizado, principalmente diante de falas de especialistas (três ocorrências), o que ajuda a mostrar certa busca por um discurso de objetividade. Os trechos em que a revista opta pelo verbo curinga são falas de fontes 
especializadas. Além disso, ele é usado para introduzir a fala de um extransformista que diz ter passado a ter comportamento heterossexual depois de frequentar igreja evangélica. $\mathrm{O}$ outro caso é o único exemplo usado para abordar o que seria uma igreja inclusiva. A pouca intervenção causada pelo uso de "dizer" sugere ainda o reforço da credibilidade de quem fala: valem pelos depoimentos e pelos lugares de onde enunciam.

Em contrapartida, a revista também utiliza, boa parte das vezes, aqueles que direcionam o sentido a partir daquilo que foi percebido pelo repórter. O leitor, com o uso desses verbos, é orientado à percepção de "um" sentido. Um exemplo: no trecho "Eu debochava da religião, não tinha respeito por Deus” (VEJA, 2013c, p. 41), Veja utiliza o verbo "penitenciar" para afirmar o discurso de que se distanciar da Igreja e do Deus católico é errado e sofrível. Essa passagem foi retirada do momento em que Veja narra a experiência do ex-transformista e intitulado "ex-gay”.

Ao analisar os verbos que introduzem as falas dos pastores, nota-se que há uma maior utilização dos verbos interpretativos do caráter ilocutivo (MARCUSCHI, 2007). É o caso dos verbos como "aconselhar", "sugerir" e "amenizar": "Irmão, é preciso arrumar uma mulher o quanto antes para casar e ter filhos - costuma aconselhar" (VEJA, 2013c, p. 38).

O mesmo assunto trabalhado em Junior assume, como esperado, outro formato e produz sentidos outros. A revista militante se apoia no crescimento das igrejas inclusivas e, mesmo sem citar fontes e fazendo do seu próprio discurso o discurso competente, afirma que o “(...) o movimento ganha cada vez mais projeção (...)” (JUNIOR, 2013a, p.55). A seguir a classificação dos verbos em J1:

Tabela 2 - Verbos introdutórios em J1

\begin{tabular}{|c|c|c|}
\hline Classificação & Verbos introdutórios de opinião e sentido & Total \\
\hline 1 & Dizer $^{*}(4)$, Declarar & 05 \\
\hline 4 & Acreditar & 01 \\
\hline 7 & Indicar & 01 \\
\hline
\end{tabular}

A pouca incidência de verbos introdutórios se dá por conta do caráter de discurso competente que o texto de Junior carrega, o que faz com que a revista tenha poucos entrevistados e, portanto, poucas falas para referendar por meio de verbos introdutórios. O discurso competente é aquele que, de acordo com Chauí (1986, p. 19), "pode ser proferido e aceito como verdadeiro ou autorizado (...), porque perdeu os laços com o lugar e o tempo de sua origem”. A revista, em relação aos seus 
A “Cura Gay" em revista:

O estereótipo sobre homossexual nos discursos de Veja e Junior | 33

interlocutores, coloca-se como autorizada a, mesmo transgredindo regras próprias do jornalismo, como a citação de falas e a justificativa de dados, produzir informações sobre a comunidade.

O grande número do verbo curinga "dizer", diferente de Veja, não se justifica pela função da fala da fonte ouvida, ou por sua importância, mas pelo sentido produzido pelas outras palavras do discurso de Junior:

A acusação que pesa sobre o Padre Beto é pesada: ele é acusado de cometer heresia e de ferir os dogmas da fé religiosa ao divulgar na internet suas opiniões sobre o tratamento dado pela Igreja Católica aos temas sexuais. "O referido padre feriu a Igreja com suas declarações consideradas graves contra os dogmas da Fé Católica, contra a moral e pela deliberada recusa de obediência ao seu pastor (obediência essa que prometera no dia de sua ordenação sacerdotal), incorrendo, portanto, no gravíssimo delito de heresia e cisma cuja pena prescrita no cânone 1364, parágrafo primeiro do Código de Direito Canônico é a excomunhão anexa a estes delitos", diz a nota (JUNIOR, 2013a, p. 56, grifo nosso).

No caso do trecho acima, Junior não utilizou o verbo introdutório de opinião para desqualificar o discurso da nota. $O$ que a revista fez foi manter palavras exclusivas do discurso da igreja e da nota publicada, como "feriu”, "graves”, “dogmas", "recusa da obediência”. Como um discurso de oposição, Junior utilizou o termo “é acusado" para desqualificar o que expõe em seguida. Percebe-se que, no texto da igreja, o padre já é considerado culpado, os verbos indicam ações que foram consumadas e, portanto, são condenadas. A revista, por outro lado, desqualifica essa posição com as palavras "acusado" e "acusação". Essas palavras retomam o sentido de "injustiça”.

Os verbos, sempre em tempos do indicativo e na voz ativa na nota da Igreja reproduzida, dão categoricamente o caráter de certeza da afirmação, enquanto Junior coloca em dúvida todo esse discurso construído pela Igreja, ao utilizar construções na voz passiva. Por fim, 
nota-se a utilização do verbo curinga "dizer", que ameniza sentidos sobre aquilo que foi dito, porque o sentido que a revista pretendia já tinha sido construído com o uso de "acusar".

\section{CONSIDERAÇÕES FINAIS}

Estereótipos foram frequentemente retomados e ressaltados durante a constituição e a formulação do discurso das duas revistas sobre a "Cura Gay". Uma dessas regularidades e evidências está na cristalização de um imaginário de homossexual masculino necessariamente afeminado, que permeou a entrevista do deputado e pastor Marco Feliciano em Veja. A revista ainda estabeleceu a relação vaidade $\mathrm{x}$ homossexualidade no próprio entrevistado, tanto pelos adjetivos que usou, quanto pela ironia das perguntas, além da relação que construiu entre "metrossexualidade" e "homossexualidade". Ou seja: o gay é representado como aquele que é vaidoso e se cuida do ponto de vista estético, uma forma frequente de enxergar a homossexualidade pela sociedade.

Quando o pastor Feliciano aparecia nas reportagens de Junior, era colocado como o vilão, como aconteceu no momento em que a revista relacionou a "cura gay" com o deputado, na entrevista com Daniela Mercury. De fato, isso acontece mais pela ligação de Feliciano com a igreja evangélica do que com a política, uma vez que os direitos civis dos gays avançam no âmbito político e a religião apresenta-se como uma espécie de freio.

Os heróis da militância, representados por Junior, aparecem também em diferentes estereótipos: 1) com a cantora Daniela Mercury, que assumiu publicamente a homossexualidade e, com palavras da revista, tornou-se "diva", rainha e ícone das lutas pelos direitos gays, 2) com as igrejas inclusivas que assumiram o papel do herói que sofre por ser rejeitado tanto pela sociedade quanto pelas outras igrejas evangélicas e 3) com o Padre Beto, que enfrentou a própria opção religiosa e sofreu a excomunhão por ser a favor dos direitos civis homossexuais.

Com todas essas imagens, Junior deu o tom encorajador e positivo para suas reportagens, mesmo quando o assunto é dos mais delicados para a vida de um gay. Mesmo que a "Cura Gay" seja um retrocesso para as lutas homossexuais, bem como para seus direitos e para a Medicina, a militância dá um tratamento ao assunto da forma mais positiva que encontra, através dos estereótipos heroicos que produz.

As igrejas inclusivas, em Veja, não foram representadas da mesma forma, embora também foram citadas nas reportagens. Enquanto Junior 
A "Cura Gay" em revista:

O estereótipo sobre homossexual nos discursos de Veja e Junior | 35

prevê o crescimento e aceitação dessas denominações religiosas, Veja coloca essa opção como sendo minoria, e perde o caráter encorajador que a revista gay cria.

Apesar do aspecto militante, mesmo Junior não consegue desvincular a promiscuidade da imagem do homossexual masculino. Isso acontece não só pelos ensaios eróticos que dominavam as publicações, mas também pelo discurso sobre a vida sexual desregrada do gay, presente na revista. Nesse sentido, a revista não se distancia de Veja, que também faz circular esse mesmo estereótipo.

Com todos os acontecimentos sobre a homossexualidade, sobretudo na CDHM, os manifestantes gays e simpatizantes que protestaram pelos direitos homossexuais e em prol da exclusão do projeto "Cura Gay" também ganharam diferentes imagens nas duas revistas: o que circulou em Junior fazia referência ao protesto democrático, ao direito de protestar, o que convidava o seu leitor também a participar das manifestações e encorajava a lutar por tudo aquilo que acreditava ser necessário mudar no país (como foi dito em J2). Enquanto isso, Veja os colocou na posição de baderneiros violentos, claramente menosprezando as causas homossexuais.

Impossível seria não notar os traços históricos recuperados pelas duas revistas. Ambas colocaram a igreja como o maior desafio das lutas homossexuais, embora a "Cura Gay" seja um projeto mais relacionado à Psicologia e à Medicina do que à religião. Veja deixa sua posição clara em relação aos avanços dessas lutas, ou seja, a necessidade de tratar os assuntos com a "máxima cautela”. Essas considerações mostram que o caráter de assujeitamento do dizer aos fatos históricos e a imagem de um interlocutor. A revista, de fato, ressalta as lutas gays, mas permanece com o seu discurso sexista/heteronormativo, inclusive, com base nesses mesmos acontecimentos.

Junior manteve as características da mídia homossexual do período: boa parte das suas páginas dedicada aos ensaios eróticos masculinos, o vocabulário popularmente conhecido pelos gays (como o uso das palavras "diva" e "rainha", gírias homossexuais), a abordagem de temas conflituosos e o sentido positivo das reportagens. A "Cura Gay" é colocada nas páginas de forma sutil, como um obstáculo superado. Porém, mesmo com a militância, sobredeterminado pela história como sempre será o discurso, Junior materializa deslizes próprios da opacidade do dizer: tem seu discurso imerso, algumas vezes, nas águas do moralismo, como mostra o estereótipo do erotismo e da promiscuidade. 


\section{REFERÊNCIAS}

AMOSSY, Ruth; PIERROT, Anne. Estereotipos y clichés. Buenos Aires: Eudeba, 2005.

CHAUÍ, Marilena. O discurso competente. In: Cultura e democracia - o discurso competente e outras falas. São Paulo: Cortez, 1986, p. 15-25.

FOUCAULT, Michel. A ordem do Discurso. 5. ed. São Paulo: Edições Loyola, 1999.

GREGORI, Antônio Eduardo. A imprensa homossexual no Brasil: 20 anos de história. 1998. Trabalho de Conclusão de Curso (Bacharel em Jornalismo) - Centro de Linguagem e Comunicação, Pontifícia Universidade Católica de Campinas, Campinas.

KUCINSKI, Bernardo. Jornalistas e revolucionários nos tempos da imprensa alternativa. São Paulo: Scritta Editorial, 1991.

LIMA, Marcus Antônio Assis. Breve Histórico da Imprensa Homossexual no Brasil, Revista Cronos, Pedro Leopoldo, 2011, pp. 21-30.

MARCUSCHI, Luiz Antônio. A ação dos verbos introdutórios de opinião. In: Fenômenos da linguagem: reflexões semânticas e discursivas. Rio de Janeiro: Lucerna, 2007, p. 146-168.

MARQUES DE MELO, José. Jornalismo opinativo. 3. ed. Campos do Jordão: Mantiqueira, 2006.

ORLANDI, Eni P. Análise de discurso - princípios e procedimentos. 8. ed. Campinas: Pontes, 2012.

. Discurso em Análise: Sujeito, Sentido e Ideologia. 3. ed. Campinas: Pontes, 2016.

PÊCHEUX, Michel. Semântica e discurso. Campinas: Unicamp, 1989.

PEREIRA, Taís Assunção. Os estereótipos nos meios de comunicação. In: SILVA, Rafael Souza. Discursos simbólicos da mídia. São Paulo: Paulinas, 2005, p. 73-88.

SANTOS, Joseylson; VELOSO, Maria do Socorro. Corpo e Sentimento 46 anos de imprensa gay no Brasil. XXXII Congresso Brasileiro de Comunicação. Anais... Curitiba: Intercom, 2009. Disponível em: $>$ http://www.bocc.ubi.pt/pag/santos-joseylson-veloso-maria-corpoe-sentimento.pdf< Acesso em: 12 out. 2017.

SILVA, Tereza Santos. A subjetividade aparente dos operadores argumentativos na construção do texto jornalístico. Working Papers, Florianópolis, vol. 2, n. 1, jul./dez. 1997. Disponível em: 
A “Cura Gay" em revista:

O estereótipo sobre homossexual nos discursos de Veja e Junior | 37

>https://periodicos.ufsc.br/index.php/workingpapers/article/do wnload/661/1628<.Acesso em: 12 out. 2017.

VIEIRA, Luciana Leila Fontes. As múltiplas faces da homossexualidade na obra freudiana. Mal-Estar e Subjetividade. v. 9, n. 2, Fortaleza, jun-2009. Disponível em: http://pepsic.bvsalud.org/scielo.php?script=sci arttext\&pid=S151 8-61482009000200006. Acesso em: 04 nov. 2017.

\section{Periódicos: revista Veja}

"EU acredito no diálogo". Veja, São Paulo, ano 46, mar. 2013. Páginas Amarelas.

A REVELAC̣̃̃O pública de Daniela. Veja, São Paulo, ano 46, abr. 2013. NOS BASTIDORES da Cura Gay. Veja São Paulo, São Paulo, ano mar. 2013. Suplemento.

\section{Periódicos: revista Junior}

FÉ INCLUSIVA: as igrejas que acolhem os gays só crescem. Junior, São Paulo, ano_, mai. 2013.

DANIELA Mercury: entrevista com a Diva. Junior, São Paulo, ano jun. 2013.

O PAÍS das manifestações. Junior, São Paulo, ano jul. 2013. Eu Leitor.

Recebido em: 15/10/2018

Aceito em: 09/11/2018 